University of Nebraska - Lincoln

DigitalCommons@University of Nebraska - Lincoln

8-19-2000

\title{
Fermentation Strategies for Recombinant Protein Expression in the Methylotrophic Yeast Pichia pastoris
}

Wenhui Zhang

Mehmet Inan

Michael M. Meagher

mmeagher@unl.edu

Follow this and additional works at: https://digitalcommons.unl.edu/chemengbiochemeng

Part of the Biochemical and Biomolecular Engineering Commons

Zhang, Wenhui; Inan, Mehmet; and Meagher, Michael M., "Fermentation Strategies for Recombinant Protein Expression in the Methylotrophic Yeast Pichia pastoris" (2000). Papers in Biochemical Engineering. 11.

https://digitalcommons.unl.edu/chemengbiochemeng/11

This Article is brought to you for free and open access by the Chemical and Biomolecular Engineering Research and Publications at DigitalCommons@University of Nebraska - Lincoln. It has been accepted for inclusion in Papers in Biochemical Engineering by an authorized administrator of DigitalCommons@University of Nebraska - Lincoln. 


\title{
Fermentation Strategies for Recombinant Protein Expression in the Methylotrophic Yeast Pichia pastoris
}

\author{
Wenhui Zhang, Mehmet Inan, and Michael M. Meagher* \\ Biological Process Development Facility, Department of Chemical Engineering, University of Nebraska-Lincoln, \\ Lincoln, Nebraska 68583-0919, USA
}

\begin{abstract}
Fermentation strategies for recombinant protein production in Pichia pastoris have been investigated and are reviewed here. Characteristics of the expression system, such as phenotypes and carbon utilization, are summarized. Recently reported results such as growth model establishment, application of a methanol sensor, optimization of substrate feeding strategy, DOstat controller design, mixed feed technology, and perfusion and continuous culture are discussed in detail.
\end{abstract}

Keywords: Pichia pastoris, methylotrophic yeast, fed-batch growth, fermentation optimization, growth modeling, recombinant protein expression

\section{INTRODUCTION}

Prokaryotic expression systems are often preferred for the economical production of heterologous proteins from eukaryotic cDNAs. However, some eukaryotic proteins that are produced in prokaryotic cells are unstable or may lack biological activity. Yeast offers certain advantages over prokaryotic hosts, and as eukaryotes, the intracellular environment is generally more suitable for correct folding of eukaryotic proteins. Yeast also has the ability to glycosylate proteins, which may be crucial for biological activity [1]. Saccharomyces cerevisiae was the first eukaryotic expression system to be used, and remains the most common due to the vast amount of information available on its genetics and physiology. However, expression of heterologous proteins in Saccharomyces is not always optimal for largescale production due to problems such as loss of the plasmid during scale-up, hyperglycosylation, and low protein yield [2]. The methylotrophic yeast, Pichia pastoris, has been developed for expression as an alternative to $S$. cerevisiae. Advantages of the Pichia expression system include: growth to very high cell densities in a simple defined medium, strongly inducible promoters, and commercially available methods, host strains, and expression vectors for genetic manipulations (Invitrogen Corporation, Carlsbad, CA, USA) [3].

\section{Phenotypes of $P$. pastoris}

The genome of $P$. pastoris contains two copies of the alcohol oxidase gene, $A O X 1$ and $A O X 2$, which allow for

\section{*Corresponding author}

Tel: +1-402-472-2342 Fax: +1-402-472-1693

e-mail: mmeagher@unl.edy growth on methanol as the sole carbon source. The $A O X 1$ promoter regulates $85 \%$ of the alcohol oxidase activity in the cell, and is the promoter used to drive heterologous protein expression in Pichia. The 'AOX1 promoter-Gene X' expression cassette is inserted into the Pichia genome along with a histidinol dehydrogenase gene (HIS4) or a drug resistant gene such as zeosin, for selection of transformed cells in his host strains, i.e. GS115 (his4). Insertion of the expression cassette into the HIS 4 or AOX 1 locus, by single crossover integration, generates a Mut ${ }^{+}$strain (methanol utilization plus), a phenotype whose growth characteristics are indistinguishable from wild type P. pastoris. Alternatively, when the expression cassette is inserted within the AOX 1 locus by double crossover gene transplacement, the $\mathrm{Mut}^{\mathrm{s}}$ strain (methanol utilization slow) is generated [2]. Another way of obtaining a Mut ${ }^{\mathrm{s}}$ phenotype is by disruption of the AOX1 gene via gene insertion i.e. KM71 (arg4 his4 aox14::SARG4) [4]. The P. pastoris KM71 strain grows very slowly in media containing methanol as the sole carbon source because of the defective $A O X 1$ gene [5].

A third host strain used for heterologous protein expression is the $\mathrm{Mut}^{-}$(methanol utilization minus) strain in which both the AOX1 and AOX2 genes are disrupted i.e. MC100-3 (arg 4 his 4 aox14::SARG4 aox24::Phis4) [6]. The alcohol oxidase defective strain, MC100-3, cannot utilize methanol as its sole carbon source. The inability to grow on methanol requires the use of alternate carbon source, such as glycerol, for growth and recombinant protein production. However non-limiting glycerol concentrations in shake flask culture can cause repression of the AOX1 promoter and may result in production of ethanol, also a strong repressor of the $A O X 1$ promoter [7].

Protease deficient strains of $P$. pastoris (SMD series) have been developed because some secreted foreign pro- 
teins are unstable in the P. pastoris culture medium. Although native proteases of $P$. pastoris are not secreted into the fermentation medium, cell lysis can occur, especially at high cell densities, releasing proteases. This problem may be overcome by using protease deficient host strains [8].

For secretion of foreign proteins, vectors contain a DNA sequence immediately following the $A O X 1$ promoter that encodes a secretion signal. Examples of secretion signals in Pichia are the $S$. cerevisiae $\alpha$-factor prepro signal sequence $[9,10]$, and the $P$. pastoris acid phosphotase gene (PHO1).

\section{Carbon Utilization and Their Regulations in Methylotrophs}

Following isolation of methanol utilizing yeast [11], the sequences of reactions of methanol oxidation and assimilation were established, and the corresponding enzymes have been isolated and well characterized [1214].

Methylotrophic yeast, belonging to genera of Pichia, Hansenula, Torulopsis and Candida, possesses a general methanol utilization pathway that is highly compartmentalized in methanol-induced microbodies, peroxisomes, and cytoplasm (Fig. 1) [13,14]. Methanol enters the peroxisome and is oxidized to hydrogen peroxide and formaldehyde by alcohol oxidase, utilizing oxygen as an electron acceptor. The peroxide is oxidized to water and oxygen by peroxisomal catalase. Formaldehyde enters the cytosol to some extent, where it forms a complex with reduced glutathione and is oxidized to carbon dioxide by two subsequent dehydrogenase reactions. In the first step, formaldehyde dehydrogenase catalyzes the production of formate, subsequently, from which carbon dioxide is generated by the action of formate dehydrogenase [15].

Methylotrophic yeast also contains the NADH dependent formaldehyde reducing enzyme, formaldehyde reductase, which reduces formaldehyde to methanol [13]. This enzyme was determined to be one of three alcohol dehydrogenases in $P$. methanolica. It has been suggested that formaldehyde reductase, together with alcohol oxidase, form the futile cycle, which regulates cellular content of formaldehyde and $\mathrm{NADH}$.

In the assimilatory pathway, formaldehyde that remains in the peroxisome reacts with xylulose-5phosphate. In this reaction, catalyzed by dihydroxyacetone synthase, two $\mathrm{C}_{3}$ compounds, dihydroxyacetone and glyceraldehyde-3-phosphate, are produced. These compounds are further metabolized in the cytosol to eventually regain xylulose-5-phosphate in a cyclic pathway. One-third of the glyceraldehyde-3-phosphate produced becomes available for central metabolism and the generation of biomass.

Methylotrophic yeast is similar to other yeast in their ability to utilize ethanol and acetate. Ethanol is oxidized through acetaldehyde to acetate, which serves to synthesize acetyl-coenzyme A. Acetyl-CoA is subsequently oxidized via enzymes of the tricarboxylic acid

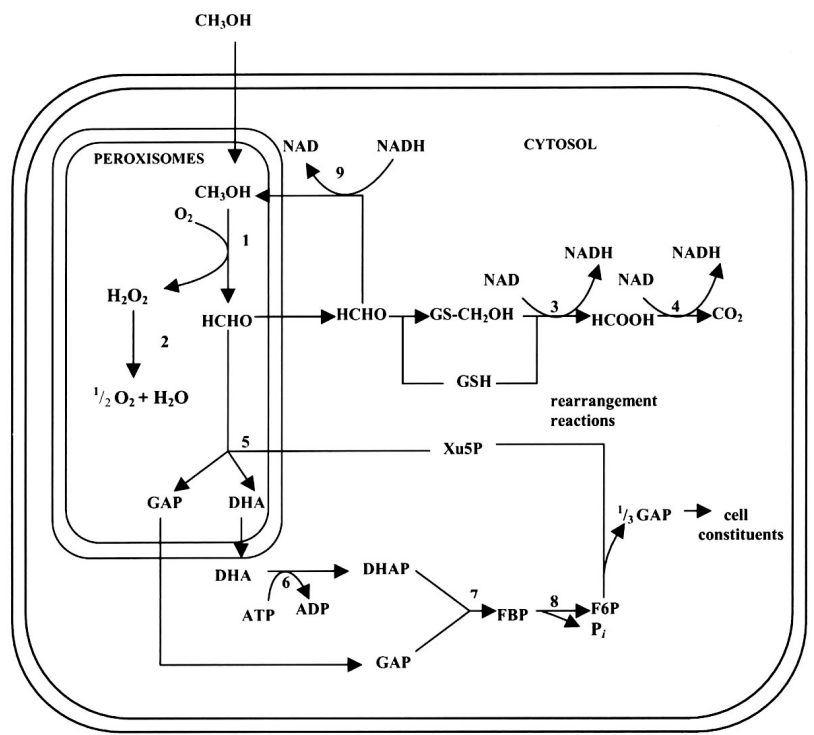

Fig. 1. Methanol metabolism pathways and their compartmentation in methylotrophic yeasts [13]. 1) alcohol oxidase, 2) catalase, 3) formaldehyde dehydrogenase, 4) formate dehydrogenase, 5) dihydroxyacetone synthase, 6) dihydroxyacetone kinase, 7) fructose-1,6-bisphosphate aldolase, 8) fructose1,6-bisphosphotase, 9) formaldehyde reductase.

cycle (citrate synthase and aconitase) and specific $\mathrm{C}_{2}$ metabolic glyoxylate cycle enzymes (isocitrate lyase and malate synthase) which are localized in another type of microbody, the glyoxysome [16].

Glycerol is utilized as a carbon source under aerobic condition by methylotrophic yeast. The catabolic pathway involves passive diffusion across the plasma membrane, phosphorylation by a glycerol kinase, and oxidation by a mitochondrial glycerol phosphate ubiquinone oxireductase [17]. Glycerol enters glycolysis after its conversion to glyceraldehyde 3-phosphate, and requires respiration to dispose of $\mathrm{NADH}$ in order to serve as an energy source.

Regulation of methanol metabolism in yeast is a very complex process including control of synthesis and activation of the corresponding enzymes as well as their degradation [14]. Synthesis of methanol metabolizing enzymes is induced by methanol, formaldeyde, and formate and is repressed by glucose and ethanol $[14,18,19]$. Regulation and glucose repression of the key enzyme in methanol oxidation, alcohol oxidase (AOX), occurs at transcription level [20,21].

Since AOX, dihydroxyacetone synthase, and catalase are all located in membrane bound peroxisomes, synthesis of these enzymes is associated with proliferation of these organelles [14]. When cultures of $H$. polymorpha or $P$. pastoris that are grown on methanol are transferred to media containing glucose or ethanol, the peroxisomes (and the enzymes contained within them) are actively destroyed. This active degradation is due to fusion of peroxisomes with vacuolar vesicles followed by proteolysis, and has been called degradative inacti- 
vation $[14,22]$.

Although the host and vector system and a fed-batch fermentation process have been developed for the $\mathrm{Mut}^{-}$ strain [7,23], the use of $\mathrm{Mut}^{-}$strain of $P$. pastoris as an expression host has been limited. After transforming the $\mathrm{Mut}^{-}$strain with the appropriate expression vector, screening for the best expression clone is difficult because the common sources of carbon, e.g. glycerol, glucose, and ethanol cannot be used since they all repress the AOX1 promoter. The Mut strain can not utilize methanol as a sole carbon source; therefore, we investigated alternate carbon and energy sources. A P. pastoris Mut $^{-}$strain expressing $\beta$-galactosidase was grown in minimal media. Results indicate that glucose, glycerol, ethanol, and acetate all repress the expression of $\beta$ galactosidase (unpublished data). However, Pichia growing in media containing trehalose, alanine, sorbitol, and mannitol expressed equivalent, or greater amounts of $\beta$-galactosidase compared to a Mut ${ }^{+}$strain. But the $\mathrm{Mut}^{-}$strain required methanol for induction of the $A O X 1$ promoter, and in the absence of methanol $\beta$ galactosidase was not expressed, further confirming that the $A O X 1$ promoter is regulated by an inductionrepression mechanism and not by derepression. [24]. On the contrary, the methanol oxidase (MOX) promoter of Hansenula polymorpha is derepressed in limited glucose and glycerol media. Chauhan et al. [25] have also found that addition of supplemental alanine and casamino acids improved the hepatitis B virus surface antigen (HBsAg) in shake flask cultures and under fermentor conditions. Interestingly enough, the addition of sorbitol decreased HBsAg expression. In continuous fermentation of $P$. pastoris, the use of sorbitol in mixed feed has improved the expression of human matrix metalloproteinases [26]. Sears et al. [27] have observed bacterial $\beta$-glucuronidase (GUS) activity when cells were grown in mannitol as the sole carbon source, but we did not observe $\beta$-galactosidase expression from cells grown on mannitol unless methanol was also added. This may have been due to differences in the expression vector or reporter gene.

Investigating alternate carbon sources in shake flask cultures will promote the use of the Mut ${ }^{-}$strain as a host and could reduce the need for explosion-proof facilities that are needed for handling large amounts of methanol required for growing the $\mathrm{Mut}^{+}$strain of $P$. pastoris. It may also reduce the time associated with screening for transformants, and for selecting the best clones for fermentation scale-up.

Previous studies $[7,23,28]$ revealed that during the batch, fed-batch, or induction phase, the use of glycerol results in ethanol production. Ethanol repression of the AOX1 promoter was investigated using the GS115 $\left(\mathrm{Mut}^{+}\right)$host, expressing intracellular $\beta$-galactosidase. The addition of $10 \mathrm{mg} / \mathrm{L}$ of ethanol at the start of methanol induction delayed $\beta$-galactosidase production and methanol utilization for four hours in shake flask experiments. When ethanol and acetate were added together, all of the ethanol was converted to acetate; this also repressed the $A O X 1$ promoter (unpublished data).

\section{Basic Fermentation Protocols}

The high salts/high cell density fermentation invention by Wegner et al. [29] provided a reference for developing $P$. pastoris fermentation technology for recombinant protein production. Using P. pastoris which expressed bovine lysozyme c2 as a model system, Brierley et al. [5] first reported a fermentation protocol for $\mathrm{Mut}^{\mathrm{s}}$ and $\mathrm{Mut}^{+}$strains, which resulted in an expression of lysozyme c2 up to $600 \mathrm{mg} / \mathrm{L}$. Similar protocols were also reported by Brierley et al. [30,31] and Siegel et al. [32]. Fermentation protocols for Pichia generally include three separate phases. First is the glycerol batch phase (GBP), in which cells are initially grown on glycerol in a batch mode. In the second phase, the glycerol fed-batch phase (GFP), a limited glycerol feed is initiated following exhaustion of the glycerol, and cell mass is increased to a desired level prior to induction. Furthermore, the AOX1 promoter is derepressed during this phase due to the absence of excess glycerol. The third phase is the methanol fed-batch phase (MFP), in which methanol is fed at a limited feed rate or maintained at some level to induce the $A O X 1$ promoter for protein expression. A limited glycerol feed can be simultaneously performed for promoting production when necessary.

Invitrogen Co. is authorized by RCT (Research Corporation Technologies, USA) to develop and sell the Pichia expression system for research purposes, and provides a product manual entitled "Pichia Fermentation Process Guidelines" (also available at http://wWw. invitrogen.com) [33]. These guidelines are mainly derived from the protocols of Brierley et al. according to its citations. The protocol discussed above is now considered be a standard one, though it may not be the optimum. Stratton et al. [34] have contributed an integral and comprehensive review for Pichia high celldensity fermentation which can also serve as a practical guideline. The purpose of this paper is to focus on those aspects not discussed or reviewed before, such as recently developed methanol feeding strategies for optimal protein production.

\section{CULTURE MEDIUM}

Basal salts medium (BSM) plus a PTM1 trace minerals solution is commonly employed for Pichia high cell density growth [33]. BSM consists of (per L) $26.7 \mathrm{~mL}$ $85 \% \mathrm{H}_{3} \mathrm{PO}_{4}, 0.93 \mathrm{~g} \mathrm{CaSO}_{4}, 18.2 \mathrm{~g} \mathrm{~K}_{2} \mathrm{SO}_{4}, 14.9 \mathrm{~g} \mathrm{MgSO}_{4}$. $7 \mathrm{H}_{2} \mathrm{O}, 4.13 \mathrm{~g} \mathrm{KOH}$, and 40.0 g glycerol; and PTM1 consists of (per L) $6.0 \mathrm{~g} \mathrm{CuSO}_{4} \cdot 5 \mathrm{H}_{2} \mathrm{O}, 0.08 \mathrm{~g} \mathrm{NaI}, 3.0 \mathrm{~g}$ $\mathrm{MnSO}_{4} \cdot \mathrm{H}_{2} \mathrm{O}, 0.2 \mathrm{~g} \mathrm{Na}_{2} \mathrm{MoO}_{4} \cdot 2 \mathrm{H}_{2} \mathrm{O}, 0.02 \mathrm{~g} \mathrm{H}_{3} \mathrm{BO}_{3}, 0.5$ $\mathrm{g} \mathrm{CoCl}_{2}, 20.0 \mathrm{~g} \mathrm{ZnCl}_{2}, 65.0 \mathrm{~g} \mathrm{FeSO}_{4} \cdot 7 \mathrm{H}_{2} \mathrm{O}, 0.2 \mathrm{~g}$ biotin and $5.0 \mathrm{~mL} \mathrm{H}_{2} \mathrm{SO}_{4}$. It is recommended that $4.35 \mathrm{~mL}$ PTM1 be added per L of BSM to compose the initial medium. The elements contained in this medium are calculated and shown in Table 1, which is close to the upper range recommended by Wegner [29]. This level of basal elements can support growth up to $130 \mathrm{~g} / \mathrm{L}$ DCW 
Table 1. Elemental content in the initial medium composed of BSM plus $0.435 \% \mathrm{v} / \mathrm{v}$ PTM1 and a comparison to Wegner's preferred rage [29]

\begin{tabular}{|c|c|c|c|}
\hline Element & $\mathrm{BSM}+4.35$ & PTM1/L & Wegner's preferred range \\
\hline Basal & $\mathrm{mol} / \mathrm{L}$ & $g / L$ & $g / L$ \\
\hline $\mathrm{P}$ & 0.232 & 7.17 & $2.2-10$ \\
\hline K & 0.282 & 11.04 & $1.5-10$ \\
\hline $\mathrm{Mg}$ & 0.061 & 1.47 & $0.3-1.2$ \\
\hline $\mathrm{Ca}$ & 0.0068 & 0.27 & $0.08-0.8$ \\
\hline S & 0.173 & 5.56 & $0.2-5$ \\
\hline Trace & $\mathrm{mmol} / \mathrm{L}$ & $m g / L$ & $m g / L$ \\
\hline $\mathrm{Fe}$ & 1.018 & 56.83 & $9-80$ \\
\hline $\mathrm{Zn}$ & 0.638 & 41.73 & $3-40$ \\
\hline $\mathrm{Cu}$ & 0.105 & 6.64 & $1-10$ \\
\hline $\mathrm{Mn}$ & 0.077 & 4.24 & $0.9-8$ \\
\hline $\mathrm{Na}$ & 0.0095 & 0.22 & - \\
\hline I & 0.0023 & 0.29 & - \\
\hline Mo & 0.0036 & 0.35 & - \\
\hline B & 0.0014 & 0.015 & - \\
\hline Co & 0.017 & 0.99 & - \\
\hline $\mathrm{Cl}$ & 1.310 & 46.45 & - \\
\hline
\end{tabular}

(about 450-500 g/L WCW) in fed-batch fermentation supplemented with PTM1. Table 1 can serve as a reference for modifying a medium when needed. Biotin is employed as a growth factor and is included in PTM1. It is recommended that PTM1 solutions be stored at room temperature to prevent biotin crystallization.

The above medium (BSM+0.435\% PTM1) will show some cloudiness when the $\mathrm{pH}$ is adjusted to 5.0 , due to the very low solubility of orthophosphate $\left(\mathrm{HPO}_{4}^{2-}\right)$ with $\mathrm{Mg}^{2+}, \mathrm{Ca}^{2+}$, and the other polyvalent cations present in PTM1 trace metals [35]. This slight precipitation is acceptable and will disappear with cell growth. But a much heavier precipitate will be induced when the $\mathrm{pH}$ is greater than 5.0 , and will cause problems such as an unbalanced nutrient supply or nutrient starvation, difficulty in cell density measurement, arduous downstream processing, etc. Therefore, Oehler et al. [36] presented an alternative medium in which sodium hexametaphosphate (or polyphosphate glass), a nonphosphate-precipitate forming compound, is employed as an alternate phosphate source to phosphoric acid. This medium consists of (per L) $25 \mathrm{~g}$ sodium hexametaphosphate, $0.93 \mathrm{~g} \mathrm{CaSO}_{4}, 18.2 \mathrm{~g} \mathrm{~K}_{2} \mathrm{SO}_{4}, 14.9 \mathrm{~g}$ $\mathrm{MgSO}_{4} \cdot 7 \mathrm{H}_{2} \mathrm{O}, 9 \mathrm{~g}\left(\mathrm{NH}_{4}\right)_{2} \mathrm{SO}_{4}, 40.0 \mathrm{~g}$ glycerol, and $0.435 \%$ PTM1. Sodium hexametaphosphate solutions must be prepared separately and filter sterilized, otherwise a heavy precipitate will occur when autoclaved together with other components. This medium will not elicit any precipitate below $\mathrm{pH} 8.5$ and can support a growth up to $450 \mathrm{~g} / \mathrm{L}$ WCW. Four recombinant proteins (three methanol induced and one constitutively expressed) were successfully produced using this medium, which demonstrates a viable alternative to using $\mathrm{BSM}+0.435 \%$ PTM 1 when fermentations are run at a $\mathrm{pH}$ greater than 5.0.
A $50 \% \mathrm{w} / \mathrm{v}$ glycerol solution containing $1.2 \% \mathrm{v} / \mathrm{v}$ PTM1, and a $100 \%$ methanol solution containing $1.2 \%$ $\mathrm{v} / \mathrm{v}$ PTM1 are recommended for use as feed solutions for the glycerol fed-batch phase and methanol fedbatch phase, respectively [33]. Supplementation with PTM1 in the feed solutions is based on findings of Siegel et al. [37] whereby trace mineral deficiencies could occur at high cell density that may decrease cell yield and limit protein expression. Siegel et al., using this method to produce bovine lysozyme, found that cell yield increased from 0.3 to $0.4 \mathrm{mg} / \mathrm{L} / \mathrm{h}$ and protein production increased from 4 to $15 \mathrm{mg} / \mathrm{L} / \mathrm{h}$, when the deficiency was corrected. This phenomenon was also observed in high cell density fermentation of the methylotrophic yeast Hansenula polymorpha and Candida boidinii in which a substantial decrease in yield occurred when the concentrations of $\mathrm{Ca}^{2+}$ and several trace elements were insufficient [38]. However, Brierley [39] found that with insulin-like growth factor I (IGF-I) production, the actual amount of PTM1 could be reduced from the recommendations set forth by Invitrogen [33]. In his fermentation process, there was only a single PTM 1 addition of $2 \mathrm{~mL} / \mathrm{L} \mathrm{BSM}$ at the start of the fermentation, and PTM1 was not included in the glycerol and methanol feed solutions. This illustrates that the PTM1 requirement may vary for different processes and proteins. It is therefore recommended that excess PTM1 be used (as described above) if one is not sure how a low level will impact cell growth or protein expression.

\section{GLYCEROL BATCH AND FED-BATCH PHASE}

The purpose for running glycerol batch and glycerol fed-batch phases is to generate a desired amount of cell mass prior to protein production. The strategies to run GBP and GFP are the same for all three phenotypes of strains: $\mathrm{Mut}^{+}, \mathrm{Mut}^{\mathrm{s}}$ and $\mathrm{Mut}^{-}$since their growth on glycerol are similar [23]. A cell density of about $100 \mathrm{~g} / \mathrm{L}$ WCW can be generated at the end of GBP when employing BSM+0.435\% PTM1 medium with $40 \mathrm{~g} / \mathrm{L}$ of glycerol. If the desired cell mass is less than $100 \mathrm{~g} / \mathrm{L}$ WCW, there is no need to run a GFP, and glycerol concentration in BSM can be modified to meet the needed amount of cell mass. We have determined that the cell yield on glycerol $\left(\mathrm{Y}_{\mathrm{x} / \mathrm{g}}\right)$ is $2.57 \mathrm{~g} \mathrm{WCW} / \mathrm{g}$ glycerol. Assuming a desired cell density of $\mathrm{X}_{\mathrm{gb}}(<100 \mathrm{~g} / \mathrm{L})$ by the end of GBP, the initial glycerol needed in BSM can be estimated as $\mathrm{X}_{\mathrm{gb}} / 2.57$. A glycerol concentration over 40 $\mathrm{g} / \mathrm{L}$ could inhibit growth in GBP [33]. Chiruvolu et al. [23] determined that a $0.5-2.4 \%$ level of ethanol was produced when the initial glycerol level was over $7 \%$, and Brierley [31] recommends a maximum of $6 \%$.

Running GFP enables the generation of high cell densities, which is one of the advantages of $P$. pastoris as an efficient expression system. The feed rate $\left(F_{\mathrm{gf}}\right)$ is usually set to a growth-limited level to avoid glycerol accumulation for derepression of the $A O X 1$ promoter [31]. Feed time $\left(t_{\mathrm{gf}}\right)$ will depend on the desired cell den- 


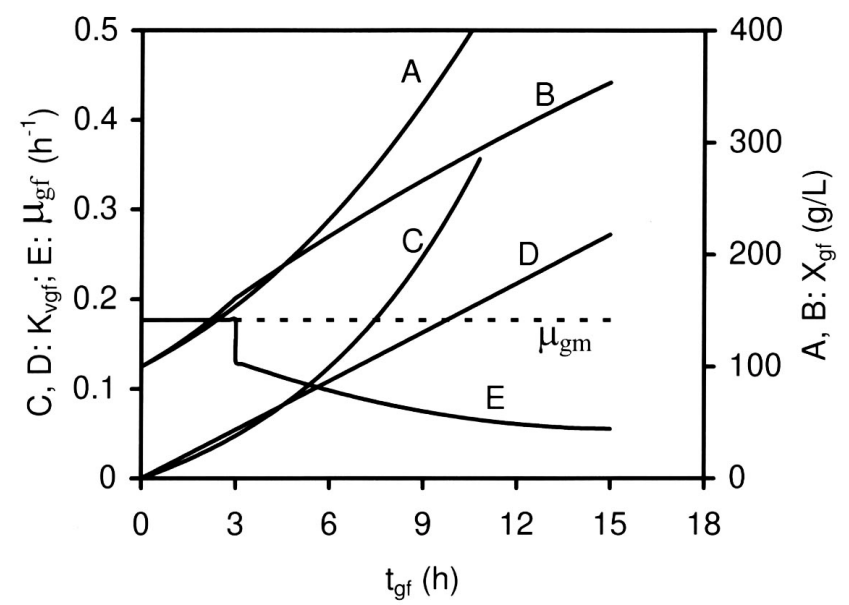

Fig. 2. Cell growth prediction in GFP. Line $A\left(X_{\mathrm{gf}}\right)$ and $\mathrm{C}\left(\mathrm{K}_{\mathrm{vgf}}\right)$ are from the exponential feed profile of Eq. (3) with $\mathrm{k}=0.9$; Line $\mathrm{B}\left(\mathrm{X}_{\mathrm{gf}}\right), \mathrm{D}\left(\mathrm{K}_{\mathrm{vgf}}\right)$ and $\mathrm{E}\left(\mu_{\mathrm{gf}}\right)$ are from feed profile $\mathrm{F}_{\mathrm{gf}}=$ $18.15 \mathrm{~mL} \cdot \mathrm{h}^{-1} \cdot \mathrm{L}^{-1}$ suggested by Invitrogen [33].

sity $\left(\mathrm{X}_{\mathrm{gf}}\right)$. Invitrogen guidelines [33] suggested a $\mathrm{F}_{\mathrm{gf}}$ of $18.15 \mathrm{~mL} \cdot \mathrm{h}^{-1} \cdot \mathrm{L}^{-1}(\mathrm{~mL}$ of $50 \% \mathrm{w} / \mathrm{v}$ glycerol $+1.2 \%$ PTM1 per h per L initial fermentation volume) over $4 \mathrm{~h}$ to produce an $\mathrm{X}_{\mathrm{gf}}$ of $180-220 \mathrm{~g} / \mathrm{L}$. We have determined the maximum specific growth rate on glycerol $\left(\mu_{g m}\right)$ to be $0.177 \mathrm{~h}^{-1}$, and the maximum glycerol specific consumption rate $\left(v_{\mathrm{gm}}\right)$ to be $0.0688 \mathrm{~g} \cdot \mathrm{g}^{-1} \cdot \mathrm{h}^{-1}$. Assuming the volume of inoculum $\left(\mathrm{V}_{\text {ino }}\right)$, samples $\left(\mathrm{V}_{\text {samp }}\right)$ and fed ammonium $\left(V_{n}\right)$ are not considered, for an $X_{g b}=100$ $\mathrm{g} / \mathrm{L}$, a prediction of $\mu_{\mathrm{g} f}, \mathrm{X}_{\mathrm{g}}$, and volume increasing factor $\left(\mathrm{K}_{\mathrm{vgf}}\right)$ in the GFP can be calculated. This is shown as Line $\mathrm{E}, \mathrm{B}$ and $\mathrm{D}$ in Fig. 2, respectively, when setting $\mathrm{F}_{\mathrm{gf}}$ $=18.15 \mathrm{~mL} \cdot \mathrm{h}^{-1} \cdot \mathrm{L}^{-1} \cdot \mathrm{K}_{\mathrm{vgf}}$ is a factor defined as Eq. (1) and involved in Eq. (2) for calculating the volume increase:

$$
\begin{aligned}
& K_{\mathrm{vgf}}=\int_{0}^{t} F_{\mathrm{gg}} d t / 1000 \\
& V_{\mathrm{gf}}=\left(1+K_{\mathrm{vgf}}\right) V_{\mathrm{BSM}}+V_{\mathrm{ino}}+V_{\mathrm{fn}}-V_{\text {samp }}
\end{aligned}
$$

Where $V_{\mathrm{g}}$ is broth volume during GFP, and $V_{\mathrm{BSM}}$ is the initial $\mathrm{BSM}$ volume in GBP. Line $\mathrm{E}$ shows that $F_{\text {of }}=$ $18.15 \mathrm{~mL} \cdot \mathrm{h}^{-1} \cdot \mathrm{L}^{-1}$ actually provides an excess of glycerol which can support cells growing at a maximum rate, $\mu_{\mathrm{gm}}=0.177 \mathrm{~h}_{-}^{-1}$ for $3 \mathrm{~h}$. The $\mu_{\mathrm{gf}}$ drops to about 0.13 $\mathrm{h}^{-1}$ immediately after $3 \mathrm{~h}$ due to exhaustion of excess glycerol, and continues to decrease thereafter. Therefore, limited growth does not occur until $3 \mathrm{~h}$ into this feeding profile. Line $\mathrm{B}$ shows that $X_{\mathrm{gf}}$ increases almost linearly after $3 \mathrm{~h}$ and takes about $15 \mathrm{~h}$ to reach $350 \mathrm{~g} / \mathrm{L}$ WCW.

For intracellular production, the methanol fed-batch phase could be as short as $10 \mathrm{~h}$ [40], thus cell mass generation up to $350-400 \mathrm{~g} / \mathrm{L}$ WCW in the GFP is required for maximum protein production in the MFP. In this case, an exponential feeding profile, where $\mu_{\mathrm{gf}}$ is set to a value close to $\mu_{\mathrm{gm}}$, is an alternative to efficiently generate high cell mass, while fermentor capacity for oxygen and heat transfer remains high enough to support the high growth rate at high cell density. Assuming we set $\mu_{\mathrm{gf}}=k_{\mathrm{gf}} \mu_{\mathrm{gm}}\left(k_{\mathrm{gf}} \leq 1\right)$, the exponential feed will have a profile of Eq. (3):

$F_{\mathrm{gf}}=k_{\mathrm{g}} \mathbf{v}_{\mathrm{gm}} X_{\mathrm{gb}} e^{k \mu_{\mathrm{gm}} t}$

Line $\mathrm{A}$ and $\mathrm{C}$ in Fig. 2 show predictions of $X_{\mathrm{gf}}$ and $K_{\mathrm{vgf}}$, respectively, when setting $k=0.9$ and $X_{\mathrm{gb}} \stackrel{\mathrm{g}}{=} 100 \mathrm{~g} / \mathrm{L}$. Compared to Line $\mathrm{B}$ and $\mathrm{D}$, respectively, this feed profile results in faster increases of $X_{\mathrm{gf}}$ and $K_{\mathrm{vgf}}$ after $t_{\mathrm{gf}}=$ $4.5 \mathrm{~h}$. Thus, it is more beneficial to run the exponential profile when a large amount of cell mass must be generated in a short time. It will only take about $9.5 \mathrm{~h}$ to reach a $X_{\mathrm{gf}}=350 \mathrm{~g} / \mathrm{L}$ and $K_{\mathrm{vgf}}=0.27$ as compared to 15 $\mathrm{h}$ when running the profile $F_{\text {of }}=18.15 \mathrm{~mL} \cdot \mathrm{h}^{-1} \cdot \mathrm{L}^{-1}$ as suggested by Invitrogen [33]. When fermentor capacity for oxygen or heat transfer becomes the growthlimiting factor, $k_{\mathrm{gf}}$ can be set to a smaller value to lower the growth rate. Then growth becomes limited by glycerol rather than oxygen supply or heat transfer, thus avoiding glycerol accumulation.

\section{METHANOL FED-BATCH PHASE FOR MUT $^{+}$STRAIN}

\section{Methanol Adaptation Improvement}

As described before, strains with different phenotypes differ in methanol assimilation. The Mut ${ }^{+}$strain can use methanol as sole carbon and energy source during protein production. It usually takes $4-5 \mathrm{~h}$ for cells to adapt to methanol after switching from glycerol when running the standard Invitrogen feed protocol $[33,34]$. This protocol suggests that a methanol feed rate of 3.6 $\mathrm{mL} \cdot \mathrm{h}^{-1} \cdot \mathrm{L}^{-1}$ (per $\mathrm{mL}$ of $100 \%$ methanol $+1.2 \% \mathrm{v} / \mathrm{v}$ PTM1/ h/L initial BSM volume) starts after stopping the glycerol feed, and lasts until cells reach a full adaptation as indicated by a decrease in $\mathrm{DO}$, followed by an increase in the feed rate. This transition phase can be shortened to 1.5-2 $\mathrm{h}$ by using an improved protocol [40], in which a limited glycerol feed is supplemented while cells are adapting to methanol. This supplement can strongly support cells to synthesize alcohol oxidase (AOX) while the $A O X$ promoter is derepressed and induced, thus accelerating the adaptation to methanol. Fig. 3 shows the profile of this transition phase. At $t_{\mathrm{tr}}=$ $0,1.5 \mathrm{~g} / \mathrm{L}$ methanol is added to the medium to start the induction, while simultaneously a glycerol feed of $F_{\text {gtr }}=$ $13.3 \mathrm{~mL} \cdot \mathrm{h}^{-1} \cdot \mathrm{L}^{-1}$ is initiated and set to decrease linearly to $4.4 \mathrm{~mL} \cdot \mathrm{h}^{-1} \cdot \mathrm{L}^{-1}$ over $2 \mathrm{~h}$ and then stop. Methanol concentration $\left(S_{\mathrm{tr}}\right)$ was monitored with a methanol sensor. It was observed that methanol was not consumed during the first half hour, and after that, $S_{\mathrm{tr}}$ started to drop and the methanol was almost depleted by $t_{\mathrm{tr}}=1.5-2 \mathrm{~h}$. This indicated that the cells were already fully modulated and ready for the methanol feed. The improved design leads to a more efficient methanol adaptation as compared to the Invitrogen protocol [33]. 


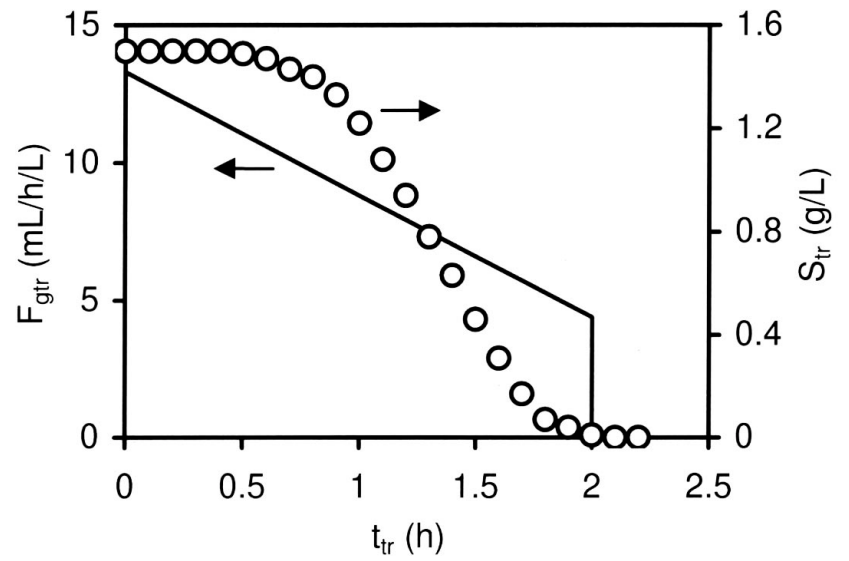

Fig. 3. Transition phase (TRP) profile. $t_{t r}$ : transition time; $F_{g t r}$ : glycerol feed rate in TRP; $S_{t r}$ : methanol concentration in TRP.

For both protocols, in order to transition successfully, one must first observe a DO spike (terminating the carbon feed and timing how long it takes for the DO to rise) to ensure that all the glycerol in GFP is exhausted before initiating the transition phase.

\section{Growth Model}

The impact of methanol concentration on growth of $\mathrm{Mut}^{+}$Pichia strains has been reported. Brierley et al. [5] observed that the $\mathrm{Mut}^{+}$strain was very sensitive to changes in the residual methanol level. Guarna et al [41] compared limited growth to growth while maintaining methanol at $0.3 \%(\mathrm{v} / \mathrm{v})$ in shake flasks. Katakura et al. [42] determined the specific growth rates on methanol at several levels. However, a growth model describing the relationship between specific growth rate and methanol concentration had not been reported until Zhang et al. [40] revealed an unstructured methanol growth model using a Mut Pichia strain for intracellular expression of Heavy-Chain Fragment $\mathrm{C}$ of Botu-linum Neurotoxin Serotype A [BoNT-A(Hc)] as a model system, which is expressed as Eq. (4), also shown in Fig. 4:

$$
\mu=\frac{0.146 S}{1.5+S+S^{2} / 8.86}
$$

Where $\mu$ is specific growth rate on methanol and $S$ is methanol concentration. Fig. 4 shows that a maximum growth rate $\mu_{\mathrm{m}}=0.08 \mathrm{~h}^{-1}$ is predicted when $\mathrm{S}=\mathrm{S}_{\mathrm{c}}=$ $3.65 \mathrm{~g} / \mathrm{L}$. The growth characteristics are divided into two regions based upon the $\mu_{\mathrm{m}}$. To the left of this point (region $\mathrm{A}$ ) is the growth limited region $\left(\mathrm{S}<\mathrm{S}_{\mathrm{c}}\right)$ and to the right (region $\mathrm{B}$ ) is the growth inhibited region $(\mathrm{S}>$ $\left.S_{c}\right)$. When $S<S_{c}$, Eq. (5), (6) and (7) were determined:

$$
\begin{aligned}
& v_{m}=0.84 \mu+0.0071 \\
& v_{n}=0.14 \mu \\
& Y_{x / m}=\mu / v_{n}=1.19-0.01 /(0.0085+\mu)
\end{aligned}
$$

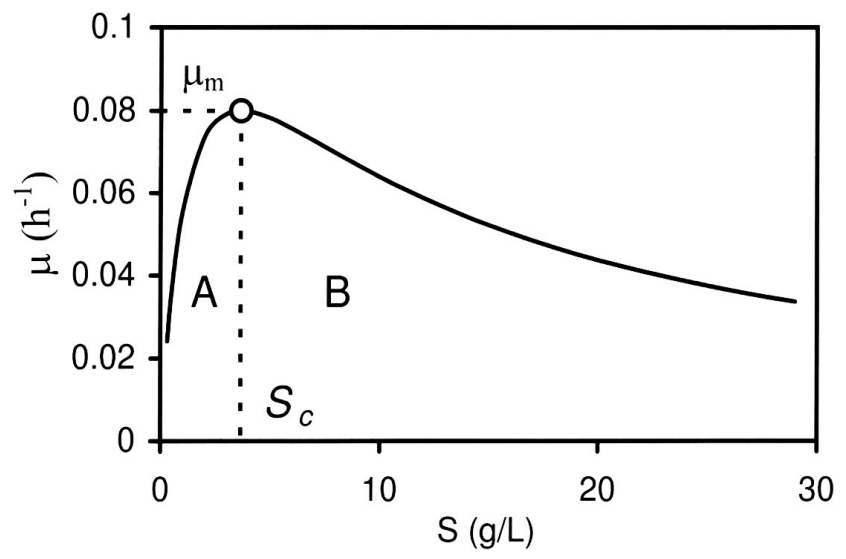

Fig. 4. Growth model predicting the relationship between specific growth rate and methanol concentration.

Where $v_{m}$ is the methanol specific consumption rate, $v_{n}$ is the ammonium specific consumption rate, and $Y_{\mathrm{x} / \mathrm{m}}$ the observed cell yield on methanol. Eq. (7) is derived from Eq. (5). From these equations, the following kinetic parameters were educed: true cell yield on methanol $Y_{\mathrm{x} / \mathrm{m}, \mathrm{t}}=1.19 \mathrm{~g} / \mathrm{g}$, on ammonium $Y_{\mathrm{x} / \mathrm{n}, \mathrm{t}}=7.14 \mathrm{~g} / \mathrm{g}$; maintenance coefficient on methanol $M_{\mathrm{m}}=0.0071$ $\mathrm{g} / \mathrm{g} / \mathrm{h}$, on ammonium $\mathrm{M}_{\mathrm{n}} \approx 0$. Based on the growth model, a methanol feeding strategy can be rationally designed to maximize protein production.

\section{Methanol Feeding Strategy}

The feeding strategy from Invitrogen's guidelines [33] is typically used as a reference to run a methanol fed-batch phase, and suggests a stepwise increase of feed rate: $0-\sim 5 \mathrm{~h}, 3.6 \mathrm{~mL} \cdot \mathrm{h}^{-1} \cdot \mathrm{L}^{-1} ; \sim 5-\sim 7 \mathrm{~h}, \sim 7.3 \mathrm{~mL}$. $\mathrm{h}^{-1} \cdot \mathrm{L}^{-1} ; \sim 7-\sim 70 \mathrm{~h}, \sim 10.9 \mathrm{~mL} \cdot \mathrm{h}^{-1} \cdot \mathrm{L}^{-1}$. Brierley [31] made some changes to this protocol for IGF-I production, namely $\sim 7-\sim 24 \mathrm{~h}, \sim 11 \mathrm{~mL} \cdot \mathrm{h}^{-1} \cdot \mathrm{L}^{-1} ; \sim 24-\sim 70 \mathrm{~h}$, $\sim 13 \mathrm{~mL} \cdot \mathrm{h}^{-1} \cdot \mathrm{L}^{-1}$. It is recommended that one perform DO spikes to make sure that growth is limited by methanol during the phase after adaptation. The entire MFP lasts approximately $70 \mathrm{~h}$ with a total of approximately $740 \mathrm{~mL}$ of methanol fed per liter of initial volume. This protocol only works when a certain amount of cell mass is generated by the end of GFP following Invitrogen's guidelines [33]. The feed rate design was developed empirically, and the resultant $\mu$ was inconstant as predicted based on our growth model [40] and shown in Fig. 5. A different growth rate could result in a different production rate in fed-batch fermentation [43-45], thus the feeding strategy must be optimized to achieve a maximum, high quality production.

Based on Eq. (5), we proposed a rational feeding strategy that can deliver a constant desired $\mu$ for a limited growth, which is expressed as Eq (8):

$$
F_{\mathrm{mf}}=(0.84 \mu+0.0071)\left(X_{\mathrm{mf} 0} V_{\mathrm{mf} 0}\right) e^{\mu t_{m f}}
$$

Where $F_{\mathrm{mf}}$ is the methanol feed rate in $\mathrm{g} / \mathrm{h}$ that accounts 


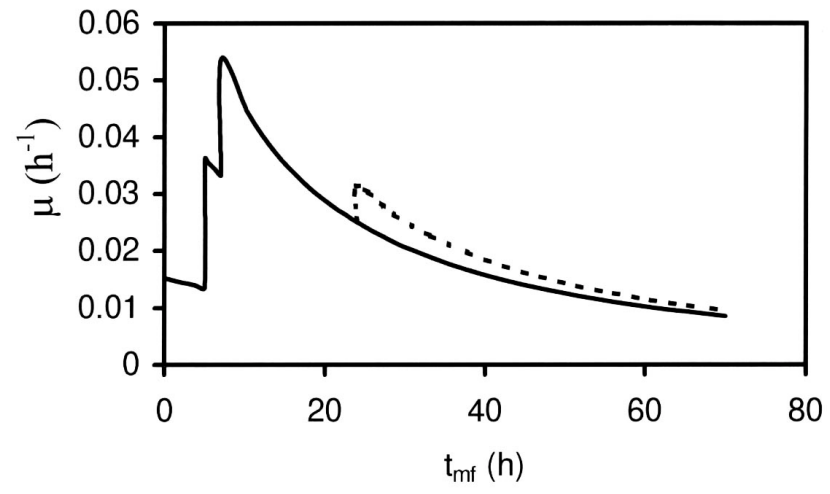

Fig. 5. Predicted $\mu$ when performing Invitrogen's feeding protocol [33]. Dotted line shows the $\mu$ corresponding to Brierley's modified feed rate after $24 \mathrm{~h}$ [31].

for total cell mass, $X_{\mathrm{mf0}}$ and $V_{\mathrm{mfo}}$ are cell density and volume at the beginning of MFP, respectively, and $t_{\mathrm{mf}}$ is the methanol feed time. This feeding strategy performs an exponential $F_{\mathrm{mf}}$ to result in a desired $\mu$, which can be optimized to maximize protein production. Fig. 6 shows the BoNT-A $(\mathrm{Hc})$ content in cells $(\alpha)$ obtained at different $\mu$, indicating that the optimum $\mu$ is $\mu_{\mathrm{c}}=$ $0.0267 \mathrm{~h}^{-1}$ for a maximum $\alpha_{\mathrm{m}}=1.72 \mathrm{mg} / \mathrm{g}$ WCW. Based on the feeding strategy in Eq. (8), and growth model Eq. (4-6), the following equations (9-14) were derived to predict the growth parameters. In this simulation, $\mu<$ $\mu_{\mathrm{m}}=0.08 \mathrm{~h}^{-1}, \mathrm{~S}<3.65 \mathrm{~g} / \mathrm{L}$, and $X_{\mathrm{mf}}<450 \mathrm{~g} \mathrm{WCW} / \mathrm{L}$, which was found to be the maximum $X_{\mathrm{mf}}$ that BSM medium supplemented with PTM1 trace minerals can support.

$$
\begin{aligned}
& X_{\mathrm{mf}} V_{\mathrm{mf}}=\left(X_{\mathrm{mf} 0} V_{\mathrm{mf} 0}\right) e^{\mu \mathrm{t}_{\mathrm{mf}}} \\
& V_{\mathrm{m}}=(0.84 \mu+0.0071)\left(X_{\mathrm{mf} 0} V_{\mathrm{mf} 0}\right)\left(e^{\mu \mathrm{t}_{\mathrm{mf}}}-1\right) / 0.79 \mu \\
& V_{\mathrm{n}}=0.14\left(X_{\mathrm{mf} 0} V_{\mathrm{mf} 0}\right)\left(e^{\mu_{\mathrm{mf}}}-1\right) / 0.9 \\
& V_{\mathrm{mf}}=V_{\mathrm{mf} 0}+V_{\mathrm{fm}}+V_{\mathrm{fn}} \\
& X_{\mathrm{mf}}=\mu X_{\mathrm{mf}}{ }^{\mu \mathrm{t}_{\mathrm{mf}}} /\left[\mu+(1.22 \mu+0.009) X_{\mathrm{mf} 0}\left(e^{\mu \mathrm{t}_{\mathrm{mf}}}-1\right)\right] \\
& S=f(\mu) \quad(\text { rewritten Eq. } 4))
\end{aligned}
$$

\section{Methanol Sensor}

Using a methanol sensor to keep $S$ constant during the MFP was another strategy Zhang et al. [40] employed to substitute for the programmed feed rate to obtain a constant $\mu$ based on the growth model Eq. (4). When growth is methanol-limited and $\mathrm{S}$ is too low to be controlled well by the sensor, the programmed method works better than methanol control, but when running a MFP at high $\mathrm{S}$, on-line methanol monitoring and control becomes necessary to keep a constant S. A Figaro model TGS822 $\mathrm{SnO}_{2}$ organic vapor sensor (Figaro Engineering Inc., Osaka, Japan) is commonly used to equip a methanol/ethanol on-line sensing device $[41,42,46,47]$. Based on the gas-liquid phase equilibrium, there are two techniques for using the sensor to monitor

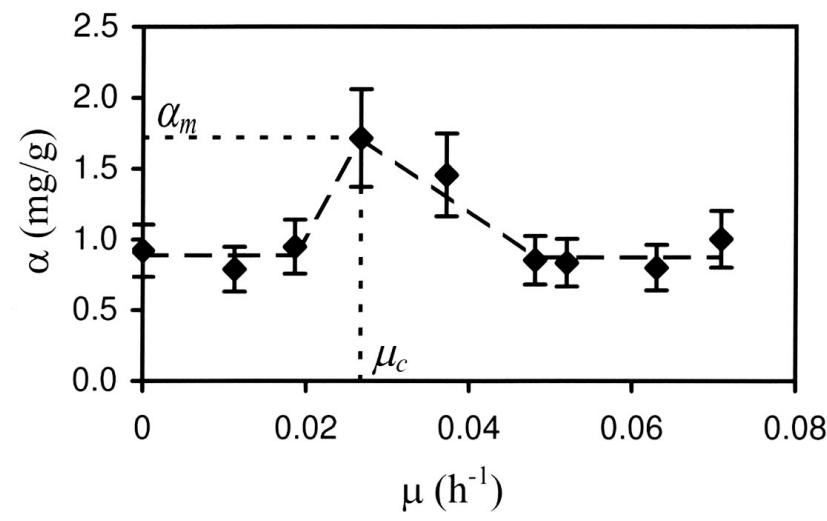

Fig. 6. Effect of $\mu$ on $\alpha$ in a methanol-limited fermentation.

the methanol in fermentation broth. One method detects the methanol vapor in off-gas $[42,46]$, while the other detects methanol vapor that permeates from the broth across a silicone tube [41,47]. A hollow silicone tube is submerged into the fermentor where methanol in the broth diffuses through the tubing, is picked up by a stream of air, and is carried to an external sensor. Both techniques have been applied to the manufacture of commercial products such as the model MC-168 Methanol Controller (PTI Instruments Inc., USA), and the model 2.1 Methanol Sensor (Raven Biotech Inc., Canada).

With a methanol sensor, Guarna et al. [41] maintained a methanol level at $0.3 \% \mathrm{v} / \mathrm{v}$ in a shake flask culture and achieved a five-fold increase in volumetric protein production over levels obtained using the conventional fed-batch protocol. Zhang et al. [46] and Katakura et al. [42] studied effects of methanol concentration on specific production rate and found that maintaining some level of methanol supplemented with glycerol feed could result in a high production rate. We used an MC-168 Methanol Controller to develop the growth model and production model [40]. Since the TGS822 sensor response is very sensitive to the gas flow rate passing through the sensor, it is critical to maintain a constant flow rate in order for the sensor to work accurately. We recently incorporated a gas flow controller (MFC 1104 Thermal Mass Controller, Dwyer Inc., USA) into the MC-168 and greatly improved the control performance. PID control of the methanol level was realized when interfaced with the AFS-BioCommand control system (New Brunswick Scientific Co., USA) or a PLC control system for our ABEC $500 \mathrm{~L}$ fermentor (Associated Bio-Engineers \& Constructions, Inc., PA, USA). Fig. 7 shows the diagram of this methanol control system. Controller ' $d$ ' directs a 10-100 $\mathrm{mL} / \mathrm{min}$ flow of carrier air while ' $e$ ' directs a 10-100 $\mathrm{mL} / \mathrm{min}$ flow of off-gas. The methanol measurable range can be adjusted by changing the off-gas to carrierair ratio. While oxygen concentration in the off-gas varies, carrier air also functions to maintain a relatively stable level of oxygen passing through the sensor to eliminate the variation effect on the sensor response. 


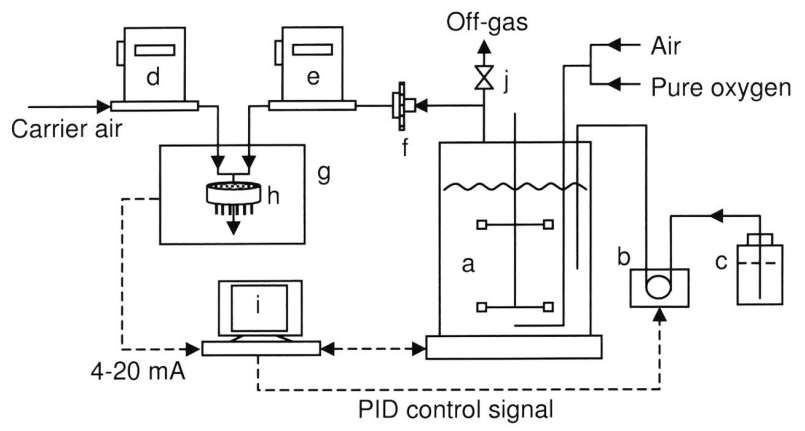

Fig. 7. Schematic diagram of a methanol control system. $\rightarrow$ mass flow direction; $\rightarrow$ controlling signal flow direction. (a) fermentor, (b) methanol feed pump, (c) methanol reservoir, (d) MFC 1104 controller for carrier air flow, (e) MFC 1104 controller for off-gas flow, (f) self-locking filter, (g) MC-168 Methanol Controller, (h) Figaro TGS822 alcohol sensor, (i) AFS-BioCommand or PLC fermentation control system, (j) valve.

The system can be protected by installing a self-locking double layer $0.8 \mu \mathrm{m}$ filter 'f' (Drummond Scientific Company, PA, USA). This system can control methanol concentration within the $0.5-30 \mathrm{~g} / \mathrm{L}$ range.

\section{Mixed Feed}

A mixed (methanol-glycerol) feeding strategy is typically used for $\mathrm{Mut}^{\mathrm{s}}$ and Mut strains in which only glycerol can be utilized as the main carbon and energy source. It was found that by applying mixed feeding to a $\mathrm{Mut}^{+}$strain, protein expression was also occasionally enhanced [42,46], while Brierley et al. [30] report that mixed feeding resulted in lower productivity than methanol feeding alone (in which a 4:1 ratio of glycerol: methanol (by weight) was fed instead of methanol). Few mixed feeding studies have been conducted. Thus, the decision as to which strategy to employ remains a matter of empirical determination. In recent studies with the intracellular production of a protein (unpublished data), we found that co-feeding glycerol, while maintaining a $20 \mathrm{~g} / \mathrm{L}$ methanol feed resulted in an approximate $50 \%$ increase of intracellular protein content as compared to that without co-feeding glycerol. This discovery illustrates that cells can tolerate high methanol levels if they are supported by a simultaneous glycerol feed. In addition, cells can maintain a high potential for production, induced by high methanol, if a sufficient supply of carbon and energy are provided by co-feeding glycerol. The methanol level and glycerol co-feeding rate need to be further optimized within this strategy.

\section{DOstat Controller}

Chung [48] designed a metabolic feed controller in which the methanol feed rate was controlled by a standard proportional-integral (PI) feedback of a closed-loop
DOstat. For maintaining a desired DO set point, this PI controller delivers an output signal, $p(t)$ (percent full scale), to control the methanol feed pump (actuator):

$$
p(t)=p_{\text {ss }}+K_{\mathrm{c}}[e(t)]+\frac{1}{\tau_{\mathrm{I}}} \int_{0}^{t} e(t) d t
$$

Where $p_{s s}$ is the output under an open-loop condition, $K_{\mathrm{c}}$ is the proportional controller constant, $\tau_{\mathrm{I}}$ the integral controller constant which is set to 2000 seconds, and $e(t)$ is the deviation of dissolved oxygen from the desired set point. Based on the metabolic and operational parameters, the controller stability criteria were derived by frequency response analysis and the Bode stability criterion. This allowed the $K_{c}$ to be decided within a certain range and changed with the metabolic and operational parameters to attain a stable DOstat. This strategy is applicable and relevant to controller design in many industrial settings where high cell densities and oxygen transfer limitation are often encountered.

\section{INDUCTION PHASE FOR MUT' ${ }^{\mathrm{s}}$ AND MUT $^{-}$STRAINS}

\section{$\mathrm{Mut}^{\mathrm{s}}$ Strain}

In a standard $\mathrm{Mut}^{\mathrm{s}}$ fermentation, maintaining an excess of methanol not exceeding $0.3 \%$ is recommended [33], and the methanol feed rate must be adjusted empirically if on-line methanol control is not available. Mixed glycerol-methanol feeding strategy was also ascertained to be highly efficient for obtaining a high productivity $[5,30,32]$ in Mut $^{\mathrm{s}}$ strains. Unfortunately, optimization on both glycerol and methanol feeding are not yet reported. Anjou et al. [49] developed a growth model on the mixed feed which was capable of predicting cell growth and methanol utilization. The model was used to design an exponential feeding strategy for a constant specific growth rate. This made it possible to optimize production based on $\mu$ in a Mut ${ }^{\mathrm{s}}$ mixed feed fermentation. Sorbitol and alanine were considered to be non-repressing carbon sources and were used in $\mathrm{Mut}^{\mathrm{s}}$ mixed substrate fermentations to increase protein production [26]. Chauhan et al. [25] also found that supplementing with a limited amount of casamino acids or alanine in place of glycerol in a mixed substrate fermentation resulted in a two-fold increase in expression level of HBsAg (intracellular) compared to that without the supplement. For substrate feed rate control, the methanol sensor and DOstat described above for $\mathrm{Mut}^{+}$strain could be also applied to Mut ${ }^{\mathrm{s}}$.

\section{Mut $^{-}$Strain}

Mut $^{-}$strains cannot assimilate any methanol due to the AOX deficiency, so glycerol is the sole carbon and energy source, while methanol functions only as an inducer. In the induction phase, methanol can be maintained at about $0.5 \%(\mathrm{v} / \mathrm{v})$ while a limited glycerol feed 
is performed [7]. Few investigations have been conducted on the optimization of utilizable carbon sources and substrate feed rates for Mut ${ }^{-}$strains.

\section{OTHER FERMENTATION STRATEGIES}

\section{Perfusion and Continuous Culture}

Ohashi et al. [50] studied a perfusion culture for intracellular $\beta$-galactosidase production in a $\mathrm{Mut}^{+}$strain using a shaken ceramic membrane flask, in which the culture supernatant was extracted through a ceramic filter with a mean pore size of $0.2 \mu \mathrm{m}$ while fresh medium was exchanged. A $\beta$-galactosidase volumetric productivity 10 times higher than that obtained in an ordinary fed-batch shake flask culture was readily achieved by continuous replenishment of the culture supernatant, and the intracellular content of $\beta$ galactosidase was 4.4 times higher. This demonstrated a high potential for the effectiveness of perfusion culture for improving intracellular production. This strategy should be further investigated in fermentors.

Chen et al. [51] ran a continuous fermentation similar to a perfusion culture, in which a rotary membrane separation system was employed for cell recycling to obtain high cell concentration. Thrombomodulin was produced extracellularly in a Mut strain in which expression levels reached $300 \mathrm{mg} / \mathrm{L}$. The total harvested supernatant was three times the working volume and a cell density as high as $248 \mathrm{~g}$ DCW/L $\left(\mathrm{OD}_{600}=1836\right)$ was achieved. This strategy may also be applicable to intracellular production in which high productivity usually comes from a high cell density.

Digan et al. [52] investigated a standard continuous fermentation for secreted production of bovine lysozyme c2 by a Mut strain of Pichia. When cell density reached around $120 \mathrm{~g} / \mathrm{L}$ DCW, a continuous phase was initiated with a dilution rate $0.05 \mathrm{~h}^{-1}$. The feed solution was $100 \mathrm{~g} / \mathrm{h}$ of methanol and $274 \mathrm{~mL} / \mathrm{h}$ of $4 \times \mathrm{BSM}$ for an $8 \mathrm{~L}$ working volume. Bovine lysozyme c2 concentration and cell density in the steady state were approximately $350 \mathrm{mg} / \mathrm{L}$ and $100 \mathrm{~g} / \mathrm{L} \mathrm{DCW}$, respectively. One advantage of continuous culture is high volumetric productivity, but process optimization is necessary to reach this goal.

\section{Isotopically Labeled Protein Production}

Wood et al. [53] reported the secreted production of isotopically labeled thrombomodulin in a Mut strain. For ${ }^{15} \mathrm{~N}$-labeling, $\left({ }^{15} \mathrm{NH}_{4}\right)_{2} \mathrm{SO}_{4}$ was used as the sole nitrogen source instead of $\mathrm{NH}_{4} \mathrm{OH}$ because of its lower cost than ${ }^{15} \mathrm{NH}_{4} \mathrm{OH}$. A mixture of $\mathrm{KOH}$ and $\mathrm{NaOH}$ was used to maintain $\mathrm{pH}$. It was found that the high ionic strength due to formation of $\mathrm{Na}_{2} \mathrm{SO}_{4}$ and $\mathrm{K}_{2} \mathrm{SO}_{4}$ was built up and inhibited growth, however this problem was solved with batch-wise addition of $\left({ }^{15} \mathrm{NH}_{4}\right)_{2} \mathrm{SO}_{4}$ and refreshing the medium to remove the accumulated salts. Using this protocol, cells were successfully grown and the labeled protein was produced. For ${ }^{13} \mathrm{C}$-labeling, ${ }^{13} \mathrm{C}$-labeled glucose was used as the sole carbon source in place of glycerol because of its lower cost than ${ }^{13} \mathrm{C}$ labeled glycerol. However, a 20 minutes of limited glycerol feed prior to induction was required to derepress the AOX1 and AOX2 promoters, otherwise cells would not grow, even though the media was exchanged with fresh media at the beginning of the induction phase. This could be a special condition for Mut strains in view of our experience growing $\mathrm{Mut}^{+}$Pichia on glucose, as $\mathrm{Mut}^{+}$cells were able to adapt and utilize methanol well after $2 \mathrm{~h}$ of carbon starvation following glucose exhaustion (data not shown). In the adaptation phase, we added $1.5 \mathrm{~g} / \mathrm{L}$ methanol and monitored methanol utilization. The methanol feed was not initiated until the $1.5 \mathrm{~g} / \mathrm{L}$ methanol was used up which took about 2.5 $\mathrm{h}$. The reason for setting a $2 \mathrm{~h}$ starvation period was due to the observed ethanol production when cells were grown on glucose. The accumulated ethanol and other repressors were depleted during the starvation period. Laroche et al. [9] also reported an isotopic labeling protein production (secreted) by $\mathrm{Mut}^{+}$strain in FM22 medium. For ${ }^{13} \mathrm{C}$-labling, ${ }^{13} \mathrm{C}$-glucose was employed as sole carbon source in growth phase. When the culture was shifted from growth phase to induction phase, the medium was exchanged with fresh FM22 medium containing $0.5 \%{ }^{13} \mathrm{C}$-methanol, but no glycerol feed was applied prior to the induction. Eight additional pulses of ${ }^{13} \mathrm{C}$-methanol were supplied to the culture during $53 \mathrm{~h}$ of induction phase.

\section{Production Optimization Using RSM}

We have recently applied Response Surface methodology (RSM) to optimize $\mathrm{pH}$, temperature and glycerol feed rate in GFB for the secreted production of hookworm (Ancylostoma caninum) anticoagulant peptide ( $\mathrm{r}$ AcAP-5) [28]. The RSM is a group of statistical techniques used to evaluate relationships between one or more measured responses and a number of quantitative independent variables that may have an important effect on the measured responses. The advantage of RSM is that it requires fewer treatments than an equivalent factorial design in order to evaluate how independent variables affect the measured responses. The optimum conditions predicted by the models using this methodology were $\mathrm{pH} 7,28^{\circ} \mathrm{C}$, and $12 \mathrm{~g} / \mathrm{L} / \mathrm{h}$ glycerol feed rate. The maximum response was $1.2 \mathrm{~g} / \mathrm{L}$ yield and this correlated well with the experimental data $(1.03 \mathrm{~g} / \mathrm{L})$.

\section{Strategies to Avoid Protein Degradation}

Some proteins are susceptible to proteolytic degradation, which will lower yield and compromise protein quality. It was found that neutral proteases could be inhibited by fermentation at $\mathrm{pH} 3.0$ [31,32], and inclusion of casamino acids could decrease protease activity [54]. Both are applicable strategies. Results obtained in our laboratory [55] demonstrate that protein stability in intracellular production was improved when the 
temperature was at $25-27^{\circ} \mathrm{C}$ as compared to $30^{\circ} \mathrm{C}$. Thus optimization of production temperature may also minimize degradation. Protease deficient (SMD series) strains of $P$. pastoris have also been developed to overcome this problem, however they usually do not grow as fast as the wild type strains [8]. Recently, Kobayashi et al. [56] reported that in a secreted production of human serum albumin (rHSA), nitrogen starvation caused a sudden increase of protease activity in the culture broth, which resulted in a rapid degradation of the protein. When the ammonium concentration was below $0.3 \mathrm{mg} / \mathrm{L}$, the protease activity and a decrease in the level of rHSA in the culture broth were observed. While using an improved medium which contained higher initial concentration of ammonia and phosphoric acid, this phenomenon was prevented and a stable production of rHSA of around $1.4 \mathrm{~g} / \mathrm{L}$ was achieved. It was also found that $\mathrm{pH} 4.3$ activated the potential protease activity and caused a high degradation while no degradation occurred at $\mathrm{pH}$ over 5.9.

\section{Strategies for Strains with the GAP and FLD1 Promotors}

Recently the Pichia pastoris glycerolaldehyde-3phosphate dehydrogenase gene (GAP) [57] and glutathione-dependent formaldehyde dehydrogenase (FLD1) [58] promoters have been isolated and employed for expression of heterologous protein production as an alternative to the $A O X 1$ promoter. The GAP promoter provides constitutive expression on a variety of carbon sources such as glucose, glycerol and methanol, reaping the benefit of not being dependent on methanol for induction since methanol can be a potential fire hazard. The use of the GAP promoter is limited to expression of proteins that are non-toxic to the cell. The FLD1 promoter can be induced by either methanol or methylamine in glucose-containing media. Comparable protein expression to the AOX1 promoter was obtained from the FLD1 and GAP promoters [57,58]. The plasmids carrying the GAP promoters are also available commercially from Invitrogen Corporation (Carlsbad, CA, USA). Use of these new systems for protein expression has not yet been fully explored, and fermentation development is requisite for those applications employing the FLD1 and GAP promoters.

Acknowledgements We gratefully thank Karen J. Potter (BPDF, UNL) for her useful comments in the composition of this article.

\section{NOMENCLATURE}

$\begin{array}{ll}\text { AOX } & \text { alcohol oxidase } \\ \text { BSM } & \text { basal salts medium } \\ \text { DO } & \text { dissolved oxygen } \\ F_{\text {gf }} & \text { glycerol feed rate in GFP, mL } 50 \% \text { glycerol+ } \\ & 1.2 \% \text { PTM } 1 \cdot \mathrm{h}^{-1} \cdot \mathrm{L}^{-1} \text { initial BSM volume }\end{array}$

$F_{\text {gtr }} \quad$ glycerol feed rate in TRP, mL 50\% glycerol+

$1.2 \% \mathrm{PTM} 1 \cdot \mathrm{h}^{-1} \cdot \mathrm{L}^{-1}$ initial BSM volume

$F_{\mathrm{mf}} \quad$ methanol feed rate in MFP, g/h

GBP glycerol batch phase

GFP glycerol fed-batch phase

$K_{c} \quad$ the proportional constant of PI controller in Eq. (15)

$k_{\mathrm{gf}} \quad$ growth limited degree, $<1$

$K_{\mathrm{vgf}} \quad$ volume increasing factor in GFP defined as in Eq. (1), L/L

MFP methanol fed-batch phase

$M_{\mathrm{m}} \quad$ maintenance coefficient on methanol, $\mathrm{g} \mathrm{MeOH} \cdot\left(\mathrm{g} \mathrm{wcw}^{-1} \cdot \mathrm{h}^{-1}\right.$

$M_{\mathrm{n}} \quad$ maintenance coefficient on ammonium, g $28 \%$ ammonium $\cdot(\mathrm{g} \mathrm{wcw})^{-1} \cdot \mathrm{h}^{-1}$

PTM1 trace minerals solution for $P$. pastoris growth

RSM response surface methodology

$\mathrm{S}$ methanol concentration in MFP, $\mathrm{h}^{-1}$

$S_{c} \quad$ predicted methanol concentration resulting in a $\mu_{\mathrm{m}}, \mathrm{g} / \mathrm{L}$

$S_{\mathrm{tr}} \quad$ methanol concentration in TRP, g/L

$t_{\mathrm{gf}} \quad$ glycerol feeding time in GFP, $\mathrm{h}$

$t_{\mathrm{mf}} \quad$ methanol feed time in MFP, $\mathrm{h}$

TRP methanol transition phase

$t_{\text {tr }} \quad$ transition time, $\mathrm{h}$

$V_{\text {BSM }} \quad$ BSM volume at initial GBP, L

$V$

$V_{\text {ino }}^{\text {gf }}$

$V_{\mathrm{m}}^{\text {ino }}$

$V_{\mathrm{mf}}^{\mathrm{m}}$

$V_{\mathrm{mf0}}^{\mathrm{mf}}$

$V_{\mathrm{n}}^{\mathrm{mfo}}$

$V_{\text {samp }}^{\text {n }}$

WCW

$X_{\mathrm{gb}}$

$X_{\mathrm{mf}}$

$X_{\mathrm{mf} 0}$

$Y_{\mathrm{x} / \mathrm{g}}$

$Y_{\mathrm{x} / \mathrm{m}}$

$Y_{\mathrm{x} / \mathrm{m}, \mathrm{t}}$

$Y_{\mathrm{x} / \mathrm{n}, \mathrm{t}}$

broth volume in GFP, L

inoculum volume, $\mathrm{L}$

fed methanol volume in MFP, L

broth volume in MFP, L

broth volume at the beginning of MFP, L

fed $28 \%$ ammonium volume, $\mathrm{L}$

sampled volume, $\mathrm{L}$

wet cell weight by centrifuge at $2000 \times \mathrm{g}$

cell density in GBP, g WCW/L

cell density in MFP, g WCW/L

cell density at the beginning of $\mathrm{MFP}$,

g WCW/L

cell yield on glycerol, g WCW/g glycerol

observed cell yield on methanol, g WCW/g methanol

true cell yield on methanol, g WCW/g methanol

$\alpha \quad$ BoNT-A $(\mathrm{Hc})$ protein content in cells, $\mathrm{mg} / \mathrm{g}$ WCW

$\alpha_{\mathrm{m}} \quad$ maximum $\alpha$ at $\mu=\mu_{\mathrm{c}}, \mathrm{mg} / \mathrm{g} \mathrm{WCW}$

$\mu \quad$ specific growth rate on methanol, $\mathrm{h}^{-1}$

$\mu_{c} \quad$ optimum $\mu$ to obtain $\alpha_{\mathrm{m}}, \mathrm{h}^{-1}$

$\mu_{\mathrm{gf}} \quad$ specific growth rate in GFP, $\mathrm{h}^{-1}$

$\mu_{\mathrm{gm}} \quad$ maximum specific growth rate on glycerol, $\mathrm{h}^{-1}$

$\mu_{\mathrm{m}}$ predicted maximum specific growth rate on methanol, $\mathrm{h}^{-1}$

$v_{\mathrm{gm}} \quad$ maximum glycerol specific consumption rate, g glycerol $\cdot \mathrm{h}^{-1} \cdot(\mathrm{g} \mathrm{wcw})^{-1}$

methanol specific consumption rate in MFP, $\mathrm{g}$ methanol $\cdot \mathrm{h}^{-1} \cdot(\mathrm{g} \mathrm{wcw})^{-1}$

$v_{\mathrm{m}}$

$v_{\mathrm{n}} \quad$ ammonium specific consumption rate, g $28 \%$ ammonium hydroxide $\cdot \mathrm{h}^{-1} \cdot(\mathrm{g} \mathrm{wcw})^{-1}$ 


\section{REFERENCES}

[1] Cregg, J. M., J. F. Tschopp, C. Stillman, R. Siegel, M. Akong, W. S. Craig, R. G. Buckholz, K. R. Madden, A. Kellaris, G. R. Davis, B. L. Smiley, J. Cruze, R. Torregrossa, G. Velicelebi, and G. P. Thill (1987) High-level expression and efficient assembly of hepatitis B surface antigen in the methylotrophic yeast, Pichia pastoris. Biotechnology 5 : 479-485.

[2] Romanos, M. A., C. A. Scorer, and J. J. Clare (1992) Foreign gene expression in yeast: a review. Yeast 8: 423-488.

[3] Cregg, J. M., T. S. Vedvick, and W. C. Raschke (1993) Recent advances in the expression of foreign genes in Pichia pastoris. Biotechnology 11: 905-910.

[4] Cregg, J. M. and K. R. Madden (1987) Development of yeast transformation systems and construction of methanol-utilization-defective mutants of Pichia pastoris by gene disruption. pp. 1-18 In: G. G. Stewart (ed.) Biological Research on Industrial Yeast. vol. II. CRC Press, Boca Raton, USA.

[5] Brierley, R. A., C. Bussineau, R. Kosson, A. Melton, and R. S. Siegel (1990) Fermentation development of recombinant Pichia pastoris expressing the heterologous gene: bovine lysozyme. Ann. NY Acad. Sci. 589: 350-362.

[6] Cregg, J. M., K. R. Madden, K. J. Barringer, G. P. Thill, and C. A. Stillman (1989) Functional characterization of the two alcohol oxidase genes from the yeast Pichia pastoris. Mol. Cell Biol. 9: 1316-1323.

[7] Chiruvolu, V., J. M. Cregg, and M. M. Meagher (1997) Recombinant protein production in an alcohol oxidasedefective strain of Pichia pastoris in fed-batch fermentations. Enzyme Microb. Technol. 21: 277-283.

[8] Gleeson, M. A., C. E. White, D. P. Meininger, and E. A. Komives (1998) Generation of protease-deficient strains and their use in heterologous protein expression. Methods Mol. Biol. 103: 81-94.

[9] Laroche, Y., V. Storme, J. De Meutter, J. Messens, and M. Lauwereys (1994) High-level secretion and very efficient isotopic labeling of tick anticoagulant peptide (TAP) expressed in the methylotrophic yeast, Pichia pastoris. Biotechnology 12: 1119-24.

[10] Clare, J. J., F. B. Rayment, S. P. Ballantine, K. Sreekrishna, and M. A. Romanos (1991) High-level expression of tetanus toxin fragment $\mathrm{C}$ in Pichia pastoris strains containing multiple tandem integrations of the gene. Biotechnology 9: 455-460.

[11] Ogata, K., H. Nishikawa, and M. Ohsugi (1969) A yeast capable of utilizing methanol. Agric. Biol. Chem. 33: 15191520.

[12] Harder, W., Y. A. Trotsenko, L. V. Bystrykh, and T. Egli (1986) Metabolic regulation in methylotrophic yeasts. pp. 139-149 In: H. W. Verseveld and J. A. Duine (eds). Microbial growth on C1 compounds. Proceedings of the 5 th international symposium on microbial growth on C1com-pounds. Kluwer Academic Publishers. Biological Center of the University of Groningen, Haren, the Netherlands.

[13] Sibirny, A. A., V. I. Titorenko, M. V. Gonchar, V. M. Ubiyvovk, G. P. Ksheminskaya, and O. P. Vitvitskaya (1988) Genetic control of methanol utilization in yeasts. J. Basic. Microbiol. 28: 293-319.
[14] Veenhuis, M., J. P. Van Dijken, and W. Harder (1983) The significance of peroxisomes in the metabolism of onecarbon compounds in yeasts. Adv. Microb. Physiol. 24: 182.

[15] Gleeson, M. A. and P. E. Sudbery (1988) The methylotrophic yeasts. Yeast 4: 1-15.

[16]Sibirny, A. A., V. I. Titorenko, G. E. Teslyar, V. I. Petrushko, and M. M. Kucher (1991) Methanol and ethanol utilization in methylotrophic yeast Pichia pinus wild-type and mutant strains. Arch. Microbiol. 156: 455-462.

[17] Gancedo, C., J. M. Gancedo, and A. Sols (1968) Glycerol metabolism in yeasts. Pathways of utilization and production. Eur. J. Biochem. 5: 165-172.

[18] Sibirnyi, A. A., V. I. Titorenko, B. D. Efremov, and I. Tolstorukov (1987) Multilicity of mechanisms of carbon catabolite repression involved in the synthesis of alcohol oxidase in the methylotrophic yeast Pichia pinus. Yeast 3 : 233-241.

[19] Egli, T., J. P. v. Dijken, M. Veenhuis, W. Harder, and A. Fiechter (1980) Methanol metabolism in yeasts : Regulation of the synthesis of catabolic enzymes. Arch. Microbiol. 124: $115-121$

[20] Ellis, S. B., P. F. Brust, P. J. Koutz, A. F. Waters, M. M. Harpold, and T. R. Gingeras (1985) Isolation of alcohol oxidase and two other methanol regulatable genes from the yeast Pichia pastoris. Mol. Cell Biol. 5: 1111-1121.

[21] Roggenkamp, R., Z. Janowicz, B. Stanikowski, and C. P. Hollenberg (1984) Biosynthesis and regulation of the peroxisomal methanol oxidase from the methylotrophic yeast Hansenula polymorpha. Mol. Gen. Genet. 194: 489493.

[22] Tuttle, D. and W. Dunn (1995) Divergent modes of autophagy in the methylotrophic yeast Pichia pastoris. J. Cell Sci. 108: 25-35.

[23] Chiruvolu, V., K. M. Eskridge, J. M. Cregg, and M. M. Meagher (1998) Effects of glycerol concentration and $\mathrm{pH}$ on growth of recombinant Pichia pastoris. Appl. Biochem. Biotechnol. 75: 163-173.

[24] Tschopp, J. F., P. F. Brust, J. M. Cregg, C. A. Stillman, and T. R. Gingeras (1987) Expression of the lac Z gene from two methanol-regulated promoters in Pichia pastoris. $\mathrm{Nu}$ cleic Acids Res. 15: 3859-3876.

[25] Chauhan, A. K., D. Arora, and N. Khanna (1999) A novel feeding strategy for enhanced protein production by fedbatch fermentation in recombinant Pichia pastoris. Process Biochem. 34: 139-145.

[26] Sreekrishna, K., R. G. Brankamp, K. E. Kropp, D. T. Blankenship, J. T. Tsay, P. L. Smith, J. D. Wierschke, A. Subramaniam, and L. A. Birkenberger (1997) Strategies for optimal synthesis and secretion of heterologous proteins in the methylotrophic yeast Pichia pastoris. Gene 190: 55-62.

[27] Sears, I. B., J. O'Connor, O. W. Rossanese, and B. S. Glick (1998) A versatile set of vectors for constitutive and regulated gene expression in Pichia pastoris. Yeast 14: 783-790.

[28] Inan, M., V. Chiruvolu, K. M. Eskridge, G. P. Vlasuk, K. Dickerson, S. Brown, and M. M. Meagher (1999) Optimization of temperature-glycerol-pH conditions for a fed-batch fermentation process for recombinant hookworm (Ancylostoma caninum) anticoagulant peptide 
(AcAP-5) production by Pichia pastoris. Enzyme Microb. Technol. 24: 438-445.

[29] Wegner, E. H. (1983) Biochemical conversions by yeast fermentation at high cell densities. US Patent 4,414,329.

[30] Brierley, R. A., R. S. Siegel, C. M. Bussineau, W. S. Craig, G. C. Holtz, G. R. Davis, R. G. Buckholz, G. P. Thill, L. M. Wondrack, M. E. Digan, M. M. Harpold, S. V. Lair, S. B. Ellis, and M. E. Williams (1990) Mixed feed recombinant yeast fermentation. WO Patent 90/03431.

[31] Brierley, R. A., G. R. Davis, and G. C. Holtz (1994) Production of insulin-like growth factor-1 in methylotrophic yeast cells. US Patent 5,324,639.

[32] Siegel, R. S., R. G. Buckholz, G. P. Thill, and L. M. Wondrack (1990) Production of epidermal growth factor in methylotrophic yeast cells. WO Patent 90/10697.

[33] Invitrogen Co. (May 8, 2000) Pichia Fermentation Process Guidelines. http://www.invitrogen.com/. Invitrogen Co., San Diego, CA, USA.

[34] Stratton, J., V. Chiruvolu, and M. Meagher (1998) High cell-density fermentation. Methods Mol. Biol. 103: 107-120.

[35] Curless, C., J. Baclaski, and R. Sachdev (1996) Phosphate glass as a phosphate source in high cell density Escherichia coli fermentations. Biotechnol. Prog. 12: 22-25.

[36] Oehler, R., G. Lesnicki, and M. Galleno (1998) High cell density fermentation of Pichia pastoris using nonphosphate precipitate forming sodium hexametaphosphate as a phosphate source. In: Current topics in gene expression annual meeting. San Diego, CA, USA.

[37] Siegel, R. S. and R. A. Brierley (1989) Methylotrophic yeast Pichia pastoris produced in high-cell-density fermentations with high cell yields as vehicle for recombinant protein production. Biotechnol. Bioeng. 34: 403-404.

[38] Egli, T. and A. Fiechter (1981) Theoretical analysis of media used in the growth of yeasts on methanol. J. Gen. Microbiol. 123: 365-369.

[39] Brierley, R. A. (1998) Secretion of recombinant human insulin-like growth factor I (IGF-I). Methods Mol. Biol. 103: 149-177.

[40]Zhang, W., M. A. Bevins, B. A. Plantz, L. A. Smith, and M. M. Meagher (2000) Modeling Pichia pastoris growth on methanol and optimizing the production of a recombinant protein, the heavy-chain fragment $C$ of botulinum neurotoxin, serotype A. Biotechnol Bioeng 70: 1-8.

[41] Guarna, M. M., G. J. Lesnicki, B. M. Tam, J. Robinson, C. Z. Radziminski, D. Hasenwinkle, A. Boraston, E. Jervis, R. T. A. Macgillivray, R. F. B. Turner, and D. G. Kilburn (1997) On-line monitoring and control of methanol concentration in shake-flask cultures of Pichia pastoris. Biotechnol. Bioeng. 56: 279-286.

[42] Katakura, Y., W. Zhang, G. Zhuang, T. Omasa, M. Kishimoto, Y. Goto, and K. Suga (1998) Effect of methanol concentration on the production of human $\beta_{2}$-glycoprotein $I$ domain $V$ by a recombinant Pichia pastoris: A simple system for the control of methanol concentration using a semiconductor gas sensor. J. Ferm. Bioeng. 86: 482487.

[43] Shioya, S. (1992) Optimization and control in fed-batch bioreactors. p. 111-42 In: A. Fiechter (ed.) Advances in biochemical engineering/biotechnology. Vol. 46. Springer. Berlin.

[44] Yamane, T. and S. Shimizu (1984) Fed-batch techniques in microbial process. pp. 147-194 In: A. Fiechter (ed.) Advances in Biochemical Engineering/Biotechnology. Vol. 30. Springer. Berlin, Germany.

[45] Parulekar, S. J. and H. C. Lim (1985) Modeling, optimization and control of semi-batch bioreactors. pp. 207-258 In: A. Fiechter (ed.) Advances in Biochemical Engineering/Biotechnology. Vol. 32. Springer. Berlin, Germany.

[46] Zhang, W., Y. Katakura, T. Omasa, M. Kishimoto, and K. Suga (1997) Effect of methanol concentration on production of human $\beta_{2}$-glycoprotein $I$ domain $V$ by a recombinant Pichia pastoris. pp. 173-182 In: Annual Report of ICBiotech. International Center for Biotechnology, Osaka University, Japan.

[47] Noronha, S. B., L. W. Wagner, N. H. Matheson, and J. Shiloach (1999) Use of an ethanol sensor for feedback control of growth and expression of TBV25H in Saccharomyces cerevisiae. Biotechnol. Bioeng. 63: 285-289.

[48] Chung, J. D. (2000) Design of metabolic feed controllers: application to high-density fermentations of Pichia pastoris. Biotechnol. Bioeng. 68: 298-307.

[49] Anjou, M. C. and A. J. Daugulis (2000) Mixed-feed exponential feeding for fed-batch culture of recombinant methylotrophic yeast. Biotechnol. Lett. 22: 341-346.

[50] Ohashi, R., E. Mochizuki, Y. Kamoshita, and T. Suzuki (1998) High-level expression of the methanol-inducible beta-galactosidase gene by perfusion culture of recombinant Pichia pastoris using a shaken ceramic membrane flask. J. Ferment. Biotechnol. 86: 44-48.

[51] Chen, Y., J. Krol, J. Cino, D. Freedman, C. White, and E. Komives (1996) Continuous production of thrombomodulin from a Pichia pastoris fermentation. J. Chem. Technol. Biotechnol. 67: 143-148.

[52] Digan, M. E., S. V. Lair, R. A. Brierley, R. S. Siegel, M. E. Williams, S. B. Ellis, P. A. Kellaris, S. A. Provow, W. S. Craig, G. Velicelebi, M. M. Harpold, and G. P. Thill (1989) Continuous production of a novel lysozyme via secretion from the yeast, Pichia pastoris. Biotechnology 7: 160-164.

[53] Wood, M. J. and E. A. Komives (1999) Production of large quantities of isotopically labeled protein in Pichia pastoris by fermentation. J. Biomol. NMR. 13: 149-159.

[54]Clare, J. J., M. A. Romanos, F. B. Rayment, J. E. Rowedder, M. A. Smith, M. M. Payne, K. Sreekrishna, and C. A. Henwood (1991) Production of mouse epidermal growth factor in yeast: high-level secretion using Pichia pastoris strains containing multiple gene copies. Gene 105: 205212.

[55]Potter, K. J., M. A. Bevins, E. V. Vassilieva, V. R. Chiruvolu, T. Smith, L. A. Smith, and M. M. Meagher (1998) Production and purification of the heavy-chain fragment $C$ of botulinum neurotoxin, serotype $\mathrm{B}$, expressed in the methylotrophic yeast Pichia pastoris. Protein Expr. Purif. 13: 357-365.

[56] Kobayashi, K., S. Kuwae, T. Ohya, T. Ohda, M. Ohyama, H. Ohi, K. Tomomitsu, and T. Ohmura (2000) High-level expression of recombinant human serum albumin from the methylotrophic yeast Pichia pastoris with minimal protease production and activation. J. Biosci. Bioeng. 89: $55-61$.

[57]Waterham, H. R., M. E. Digan, P. J. Koutz, S. V. Lair, and J. M. Cregg (1997) Isolation of the Pichia pastoris glyceral- 
dehyde-3-phosphate dehydrogenase gene and regulation and use of its promoter. Gene 186: 37-44.
[58] Shen, S., G. Sulter, T. W. Jeffries, and J. M. Cregg (1998) A strong nitrogen source-regulated promoter for controlled expression of foreign genes in the yeast Pichia pastoris. Gene 216: 93-102.

[Received May 18, 2000; accepted August 19, 2000] 